\title{
An Analysis of Sustainable Activities in Japanese, Korean, and Singaporean Elementary Mathematics Textbooks
}

\author{
JeongWon Kim ${ }^{1}$ (D), JeongSuk Pang ${ }^{2 *}$ \\ 1 Sintanjin Elementary School, SOUTH KOREA \\ ${ }^{2}$ Department of Elementary Education, Korea National University of Education, SOUTH KOREA
}

Received 16 October $2021 \cdot$ Accepted 7 January 2022

\begin{abstract}
The purpose of the study was to explore how contents related to sustainable development were presented in Japanese, Korean, and Singaporean elementary mathematics textbooks. For this purpose, the contents in the textbooks were analyzed at both macro and micro levels through a mixed method research. The results showed that the sustainability-related contents were included from the third or fourth grade in all the textbooks. The related contents were involved to mathematics content domains of Numbers and Operations, Pattern, and Data and Possibilities. The sustainability-related contents were used both to introduce and to apply mathematical concepts or principles. Most of the sustainable development activities led students to solve problems by using the mathematical contents they had learned, while some other activities induced students to consider sustainability as well as to solve problems. This study is expected to give implications for textbook developers and teachers to connect sustainable development meaningfully to elementary mathematics education.
\end{abstract}

Keywords: comparative study, education for sustainable development, elementary mathematics textbooks, sustainable activity

\section{INTRODUCTION}

Sustainable development is the key idea that meets the needs of both present and succeeding generations by reconciling economic growth, social development, and environmental protection (The World Commission on Environment and Development, 1987). The United Nations (UN) has suggested the 2030 agenda which highlights 17 sustainable development goals (UN, 2015). The fourth goal of the agenda indicates that Education for Sustainable Development (ESD) makes it possible to promise inclusive and equitable education and to encourage lifelong learning opportunities for all. Several countries have made educational approaches to sustainability such as developing sustainability-related activities or changing a curriculum to focus more on sustainability development (Kennelly et al., 2011; Miedijensky \& Abramovich, 2019; Prince, 2010; Woo et al., 2012).

According to United Nations Educational, Scientific, and Cultural Organization (UNESCO), ESD is not just another auxiliary education, but an overarching paradigm that guides and transforms the existing disciplines so that they can contribute to a more sustainable future (UNESCO, 2012). Many topics inherent in sustainable development are already part of the formal education curriculum (UNESCO, 2012; Yuniarti et al., 2019). Considering that environment, society, and economy are three spheres of sustainable development, multiple issues related to these spheres are incomplete without using mathematics. Mathematics interwoven in those issues is helpful in understanding economic, social, and environmental issues. In fact, several concepts in sustainability require mathematics skills such as measuring, converting units, and mathematically modeling patterns of growth and decline (Barwell, 2018; Roe et al., 2018). Moreover, analyses of sustainability rely on mathematical representations such as tables, graphs, and mathematical equations. Levin (2015) presented equations which analyze sustainability-related situations. Furthermore, Renert (2011) suggested characteristics of sustainable mathematics education, emphasizing that mathematics

(c) 2022 by the authors; licensee Modestum. This article is an open access article distributed under the terms and conditions of the Creative Commons Attribution License (http://creativecommons.org/licenses/by/4.0/). 


\section{Contribution to the literature}

- This study explores ESD-related contents presented in elementary mathematics textbooks in Japan, Korea, and Singapore.

- Considering that ESD is an indispensable aspect of students' lives now and in the future, the first step is to examine how ESD is presented in the main subject matters such as mathematics.

- This study proposes suggestions for guidance for ESD in elementary school using mathematics textbooks.

education of today can act to reconcile the urgent needs of the future.

Given the imperative nature of sustainability issues, mathematics educational approaches for sustainability need to be set from the primary levels. As young children will become the adults of the next generation, it is critical that they be developed about sustainability issues in order to take a significant role in preserving their future. Actually, there have been movements to educate children to act in a sustainable way (Bartusevica \& Cedere, 2003; Elliott \& Davis, 2009; Hedefalk et al., 2015; Serow, 2015). However, few studies have focused on mathematics education for sustainability in elementary school. Rather, the studies related to ESD usually focused on environment education (Kang, 2010), social science education (Martínez-Medina \& Arrebola, 2019), high school students (Yuniarti et al., 2019), and prospective teachers (Joutsenlahti \& Perkkilä, 2019; Zehetmeier \& Krainer, 2011). Exceptionally, Serow (2015) suggested mathematical activities drawn from the mathematics curriculum in Australia and New Zealand for ESD in primary mathematics education.

With the importance of introducing mathematics education for sustainability development from elementary school, we need to find specific ways to do so. As textbooks are one of the main instructional materials (Choy et al., 2020; Rezat et al., 2021; Stein et al., 2007) and textbook comparative analysis can give insights on developing textbooks by identifying the similarities and differences among textbooks (Bayda \& Sutliff, 2020; Fan et al., 2013), it is necessary to scrutinize how ESD-related contents are presented in mathematics textbooks across different countries. This study investigated mathematics textbooks of Japan, Korea, and Singapore from the perspective of sustainability, with the aim of suggesting implications for how to address sustainability in elementary mathematics instructional materials.

\section{LITERATURE REVIEW}

\section{Education for Sustainable Development}

The concept of sustainable development was first introduced in the 1987 Brundtland Commission Report (The World Commission on Environment and Development, 1987). According to the report, sustainable development is "development that meets the needs of the present without compromising the ability of future generations to meet their own needs." (p. 42). For sustainable development, environmental, social, and economic dimensions have to be considered and balanced in the pursuit of meeting the needs of both present and future generations. Liu et al. (2020) explained these three dimensions of sustainability: environmental sustainability means to ensure that we are consuming our natural resources at a sustainable rate; social sustainability includes principles such as trust, reciprocity norms, and equity; economic sustainability can be achieved by limiting the waste of resources so that they can be managed in a sustainable way to reduce operational costs. These three aspects of sustainability are in a lockstep relationship in which each is influenced by and in turn influences the others.

As an imperative mean in achieving sustainable development, ESD is not merely teaching and learning knowledge and principles related to sustainability. Rather, ESD is, in a broad sense, "education for social transformation with the goal of creating more sustainable societies." (UNESCO, 2012, p. 33) A study by Hedefalk et al. (2015) defined ESD in two ways: one is ESD as a threefold approach to education based on questions concerning education about, in, and for the environment; the other is ESD as an approach to education that includes three interrelated dimensions of environment, society, and economy. Compared to the former which is a narrow definition related to environmental education, the latter has a broad aim which is defined regarding environmental, social, and economic issues. As ESD is going to be considered to have a broad aim in this work, different aspects of ESD can be found in many fields of education. Thus, it is necessary to deliberate what is taught and how it is taught with sustainability as the central theme.

\section{Contents for Education for Sustainable Development}

With high interest in sustainable development, there has been a movement to emphasize the need to educate it in schools. UNESCO (2012) emphasized reorienting curriculums from early childhood up to higher education as a main priority in implementing ESD in schools. To reorient curriculums, it is important to select and present the appropriate issues and contents in the textbooks. In this regard, the Australian Curriculum (2015), emphasizing sustainability as one of mandatory cross-curriculum priorities, connects and relates sustainability to relevant content domains and subjects. 
Some studies suggested the issues and contents regarding the three dimensions of sustainability: environment, society, and economy. For instance, Kang (2010) analyzed the content and organization of ESD reflected in the Korean environment textbooks for middle school. The analytic criteria used in the study were comprised of three dimensions of sustainable development and its related contents and topics by dimension. The following are examples of the contents in each dimension: natural resources, energy, and biodiversity are related to the environmental dimension; human rights, security, and culture are related to the social dimension; consumption and market are related to the economical dimension. The analytic criteria presented in the study are noteworthy of being able to better understand ESD as they were organized around three dimensions and their concomitant components.

In addition, McKeown et al. (2002) divided the issues of sustainable development into four sections: social and economic dimension; conservation and management of resources; strengthening the role of major groups; and means of implementation. This study suggested related issues for each section. For instance, combating poverty and changing consumption patterns related to the social and economic dimension section, while protecting the atmosphere and conservation of biological diversity related to the conservation and management of resources section. This classification is meaningful in guiding the issues of sustainable development and specific efforts to realize ESD.

Meanwhile, Martínez-Medina and Arrebola (2019) analyzed the sustainability-related activities in the social sciences textbooks of Spanish elementary education. The study suggested categories which were inductively determined to classify activities in the textbooks. The activities were categorized as human modification of the environment, energy, recycling, ethical consumerism, environmental issues, and general activities. The results of the study found that environmental issues are the most frequent in the textbooks, highlighting the importance of understanding a wider range of contents related to sustainability.

Liu et al. (2020) proposed an evaluation framework of elementary school teaching materials in Taiwan for sustainable development comprised of four levels. Each of levels in the framework corresponded to a goal, teaching scopes, learning indicators, and learning topics respectively. The study set sustainable development as a goal in level 1 and regarded ecology, energy conservation, waste reduction, and health as the teaching scopes in level 2. The learning indicators in level 3 included 10 indices such as biodiversity and vegetation amount. The final step was to relate sustainability dimensions to each learning topic. Unlike Kang (2010) which categorized contents and related topics according to sustainability dimensions, this framework first established the four levels and lastly connected them with three dimensions of sustainability. This implies that a learning topic can be used in any sustainability dimension if possible. Using the evaluation framework, educators or textbook developers can determine if the textbooks cover all the sustainable development materials and, if necessary, design additional teaching materials for areas not covered in the textbooks.

\section{Efforts to Implement Education for Sustainable Development in Elementary School}

A gradual and structured process of change is needed to implement ESD in school levels (Miedijensky \& Abramovich, 2019). UNESCO (2012) developed the ESD Toolkit which outlined basic initial steps toward creating ESD programs. They emphasized five components that could reorient a curriculum and design lessons: knowledge, issues, skills, perspectives, and values. This is meaningful in that the toolkit could assist in initiating ESD in schools, institutions, and communities and in reorienting the existing curriculum. A study by Miedijensky and Abramovich (2019) examined the process of educational change to implement education for sustainability. It reported that successfully implementing ESD into schools depends on a number of factors such as motives for change, persons involved, actions carried out, and follow-up activities.

Meanwhile, teachers need to understand how to translate and implement ESD in their instruction. Summers and Kruger (2003) described recognition and conceptualization of ESD by primary school teachers in their teaching. Nine primary school teachers were interviewed individually about how they understood sustainable development, what topics they chose for teaching, and how they set learning objectives. One of the results reported that different topics were selected depending on the grade levels. For upper level pupils, global topics such as energy and the tropical rainforest were chosen, in which the teachers needed to know a wide range of content knowledge and teaching strategies. Conversely, for lower level students, local based topics such as waste and recycling, environment in our area, and nature conservation were chosen. The study also suggested that teachers need to move from beyond a narrow focus on regarding ESD as simply protection of environment and to consider social and economic issues as well.

Few studies go beyond the connection of ESD with elementary school mathematics teaching. Exceptionally, Serow (2015) presented mathematics activities for educating sustainability in elementary education, drawn from the broad curriculum strands of measurement and geometry, numbers and algebra, and statistics and probability. Considering that each of these strands is applicable in many other countries, the recommended activities can be incorporated in mathematics classrooms. For example, "packaging" can be a 
Table 1. Japanese, Korean, and Singaporean textbooks selected for analysis

\begin{tabular}{lccc}
\hline Country & Textbook & Year published & Publisher \\
\hline Japan & 新しい算數 [New Arithmetic] 3-1, 4-1, 4-2, 5-1, 5-2, 6-1, 6-2 & 2011 & 東京書籍 \\
Korea & $\begin{array}{c}\text { (Tokyo Shoseki, 2011a-g) } \\
\text { [TOKYO SHOSEKI] }\end{array}$ & Visang \\
Singapore & $\begin{array}{c}\text { Mathematics Textbook 3-2, 4-1, 4-2, 5-2, 6-1, 6-2 } \\
\text { (MOE, 2020a-f) }\end{array}$ & 2020 & Marshall Cavendish Education \\
& $\begin{array}{c}\text { Shaping Maths Coursebook 3A, 5A, 5B, 6A, 6B } \\
\text { (Collars et al., 2014a-e) }\end{array}$ & 2013 &
\end{tabular}

*Textbooks from third to sixth grades were analyzed. Textbooks not including ESD-related contents were omitted from further analysis

measuring activity to alert students to the optimum use of resources while calculating the surface area and volume and determining the choice for reducing amounts of packaging used. Another notable example is the "garden beds" activity, targeting the strand of patterns and algebra, which focuses on recording, analyzing, and describing geometry and number patterns. The garden beds activity can link to sustainability issues in that it explores why producing local food has particular environmental benefits. The study is significant as it presents specific contents implementing ESD in relation to elementary school mathematics.

\section{Framework for Analyzing Textbooks}

There is a close relationship between the conceptualizations of a topic used in mathematics textbooks and the opportunity to learn for students afforded by the textbooks (Charalambous et al., 2010; Choy et al., 2020; Törnroos, 2005). Textbooks, as a concrete embodiment of mathematics curriculum, help make the curriculum intentions specific (Li et al., 2009; Rezat et al., 2021). Numerous studies investigated textbooks from various perspectives such as content topic coverage (Martínez-Medina \& Arrebola, 2019) and exercise problems (Fan \& Zhu, 2007; Li, 2000). More recently, in analyzing three textbooks in terms of context, content, and instructional variables, Choy et al. (2020) created a visual representation, called textbook signature, to demonstrate either the distinct conceptualizations of a topic presented on each textbook page or the layout for the frequencies of occurrence.

Generally, textbooks can be analyzed at two levels: overall structure analysis and topic-specific analysis. For example, Li et al. (2009) implemented a content analysis of textbooks at two different levels: macro and micro level. A macro level analysis explores the inclusion of content topics, performance expectations for students, content presentations, and organizational features. This type of analysis can provide a broad picture of content structures in textbooks. A micro level analysis examines mathematical treatment of specific content topics and captures the mathematical nature of the topics and their connections with other topics.

This study expands on previous studies by examining the ESD-related contents in elementary mathematics textbooks in Japan, Korea, and Singapore at both macro and micro level. Initially, a macro exploration was conducted to explore the overall structure and distribution of ESD-related contents in the textbooks. A micro exploration was followed to scrutinize the connection of the ESD-related contents with mathematics. Specifically, the study addressed the following research questions:

1. What is the overall structure of the ESD-related contents presented in the textbooks?

2. How are the ESD-related contents distributed in the textbooks?

3. How are the ESD-related contents connected to mathematics in the textbooks?

\section{METHODOLOGY}

\section{Materials}

To investigate how ESD-related contents were presented in elementary mathematics textbooks series, textbooks in Japan, Korea, and Singapore from grades 3 to 6 were selected. Japan, Korea, and Singapore are the countries that rank in the top five in TIMSS 2019 (Mullis et al., 2020). The countries have a national curriculum respectively and textbooks are aligned with the curriculum. In Korea, there is only one series of mathematics textbooks developed by the Ministry of Education (MOE). In Japan and Singapore, however, private authors or publishers have developed textbooks based on the curriculum guidelines. The series published by TOKYO SHOSEKI was chosen as the Japanese textbooks for the analysis in the study. The series, originally written in Japanese, was translated into English as needed for analysis. The Singaporean series published by Marshall Cavendish Education was chosen, which was originally written in English. In total, the following 18 mathematics textbooks in Japan, Korea, and Singapore were examined (see Table 1).

\section{Procedures}

A mixed method research was employed to include both quantitative and qualitative methods. Hesse-Biber (2010) asserts that using quantitative and qualitative data allows researchers to gain a fuller understanding of the research problems through triangulation and 

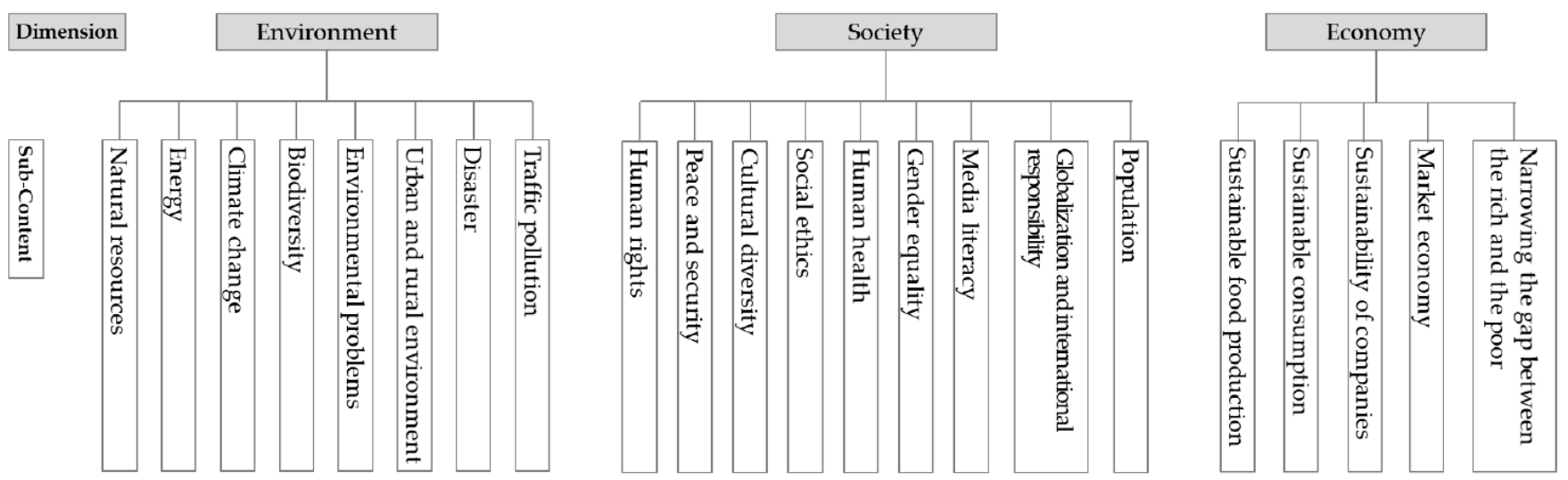

Figure 1. Organization framework of ESD-related contents

complementarity of data. In this study, a quantitative method was used to analyze how the ESD-related contents were distributed in the textbooks. Note that a quantitative analysis in the study was not to compare the focused textbooks one another. As the curriculum and organization of the textbooks in the three countries were different, the contents in the textbooks were qualitatively compared to understand in detail how the ESD-related contents were presented.

An organization framework of ESD-related contents was developed to extract and examine ESD-related contents in the textbooks. As shown in the literature review, few studies have presented an analytic framework for exploring mathematical content from an ESD prospective. In addition, as ESD requires contributions from many disciplines, not a single isolated subject, there are few studies which have distinguished ESD-related contents focusing only on mathematics. Based on the previous studies which dealt with ESD-related contents or frameworks (Kang, 2010; Liu et al., 2020; Martínez-Medina \& Arrebola, 2019; McKeown et al., 2002), sub-contents and their related topics of ESD were established. Specifically, environmental, social, and economic dimensions consisted of eight, nine, and five sub-contents, respectively (see Figure 1). The detailed topics related to each sub-content were also established to distinguish ESD-related contents in the textbooks (see Table 2).

\section{Data Analysis}

All textbooks selected for this study were analyzed in their original languages and then translated into English if necessary. The organization framework of ESD-related contents presented in Figure 1 and Table 2 was used for data analysis. Two researchers categorized and coded the contents in the textbooks independently and compared the coding results. Interclass correlation coefficient was 0.974 , indicating very high inter-rater

Table 2. Related topics by sub-contents of ESD

\begin{tabular}{lll}
\hline Dimension & Sub-content & Related topic \\
\hline Environment & Natural resources & Water, atmosphere, soil, minerals, plants, animals, natural scenery, natural \\
& resources conservation
\end{tabular}


Table 2 (continued). Related topics by sub-contents of ESD

\begin{tabular}{lll}
\hline Dimension & Sub-content & Related topic \\
\hline Economy & $\begin{array}{l}\text { Sustainable food production } \\
\text { Sustainable consumption }\end{array}$ & $\begin{array}{l}\text { Eco-friendly production, resource-circulating waste management, sustainable } \\
\text { agriculture, eco-friendly agricultural products } \\
\text { Green consumption }\end{array}$ \\
& $\begin{array}{l}\text { Market economy } \\
\text { Narrowing the gap between } \\
\text { the rich and the poor }\end{array}$ & $\begin{array}{l}\text { Corporate ethics, corporate responsibilities and duties } \\
\text { commercial sales }\end{array}$ \\
& Eradication of poverty, combating poverty \\
\hline
\end{tabular}

Table 3. Analytic framework

Level Aspect investigated

Macro Overall structure

Distribution of ESD-related contents

Micro Connections of the ESD-related contents with mathematics
Foci of question
[Grade level] In what grade level are the ESD-related contents presented?
[Dimension of ESD] Which dimensions of ESD are related?
[Mathematics content domain] Which mathematics content domains are connected?
What sub-contents and topics are presented in the ESD-related contents?
[Mathematical feature] Which mathematical feature is observed in the ESD- related contents?
[Expectation from students] What expectations from students are embedded in the ESD-related contents?

Table 4. Example of analyzing the content in the textbook

\begin{tabular}{|c|c|c|c|}
\hline Content & \multicolumn{3}{|c|}{$\begin{array}{l}\text { As the temperature of the earth is rising due to carbon dioxide, the carbon footprint should be reduced. If you use } \\
\text { a plastic bag, } 11 \text { grams of carbon are necessary. However, if you use a reusable shopping basket, no carbon is used. } \\
\text { If you use a reusable shopping basket once a week, } 52 \text { weeks per year, how much carbon footprint can be reduced } \\
\text { over a year? Also, think about ways we can use reusable shopping baskets more often. (MOE, 2020b, p. 30) }\end{array}$} \\
\hline \multirow{5}{*}{$\begin{array}{l}\text { Result of } \\
\text { analysis }\end{array}$} & \multirow[t]{3}{*}{ Macro } & Grade level & $3^{\text {rd }}$ grade \\
\hline & & Dimension-Related topic & onment- Climate \\
\hline & & Mathematics content domain & Numbers \\
\hline & \multirow[t]{2}{*}{ Micro } & Mathematical feature & pply mathematics principles \\
\hline & & Expectation from students & Context for problem-solving and considering sustainability \\
\hline
\end{tabular}

reliability. Any inconsistencies in coding were clarified by discussion.

An analysis of the mathematical contents was carried out at both macro and micro level. At the macro level, general characteristics of the textbooks in terms of sustainable development were identified, detailing in what grade level the ESD-related contents were presented; to which dimension the ESD-related contents were related; to which mathematics content domain the ESD-related contents were connected; and what subcontents and topics were presented in the ESD-related contents. In this study, the mathematics content domains were divided into Numbers and Operations, Geometry, Measurement, Pattern, and Data and Possibilities. At the micro level, mathematical features of the contents and the expectations from students were scrutinized. Mathematical features of the contents referred to whether the focused content was related to the introduction of mathematics or to the application of mathematics. The expectations from students denoted the cognitive requirement needed by students in performing activities: whether the ESD-related content of the activity was used as a sub-material or as a context for problem-solving or a context for considering sustainability along with problem-solving. Table 3 summarizes the aspects of investigation and focal questions in each analytic level.

To illustrate how the analysis of this study was implemented, an activity in the Korean mathematics textbook (MOE, 2020a) is used. The activity is to calculate how much the carbon footprint can be reduced if a reusable shopping basket is used instead of a plastic bag. The content is related to the climate topic included in the environmental dimension and is related to the Numbers and Operations mathematics content domain, intended for students to solve a given problem situation by applying the principles of calculating 2-digit $\times 2$-digit multiplication. Table 4 shows an analysis of the content.

\section{RESULTS}

Our results show textbooks variations in presenting and structuring the ESD-related contents in the selected textbooks from the three countries. The following sections are structured to provide detailed findings corresponding to the research questions, respectively.

\section{Overall Structure}

Table 5 summarizes the organization of the ESDrelated contents reflected in the mathematics textbooks. 
Table 5. Organization of the ESD-related contents in the textbooks

\begin{tabular}{lccc}
\hline Country & Grade level & Dimension & Mathematics content domain \\
Japan & 4th, 5th, 6th & Environment, society, economy & Numbers and Operations, Pattern, Data and Possibilities \\
Korea & 3rd, 4th, 5th, 6th & Environment, society, economy & Numbers and Operations, Pattern, Data and Possibilities \\
Singapore & 3rd, 5th, 6th & Environment, society, economy & Numbers and Operations, Pattern, Data and Possibilities \\
\hline
\end{tabular}

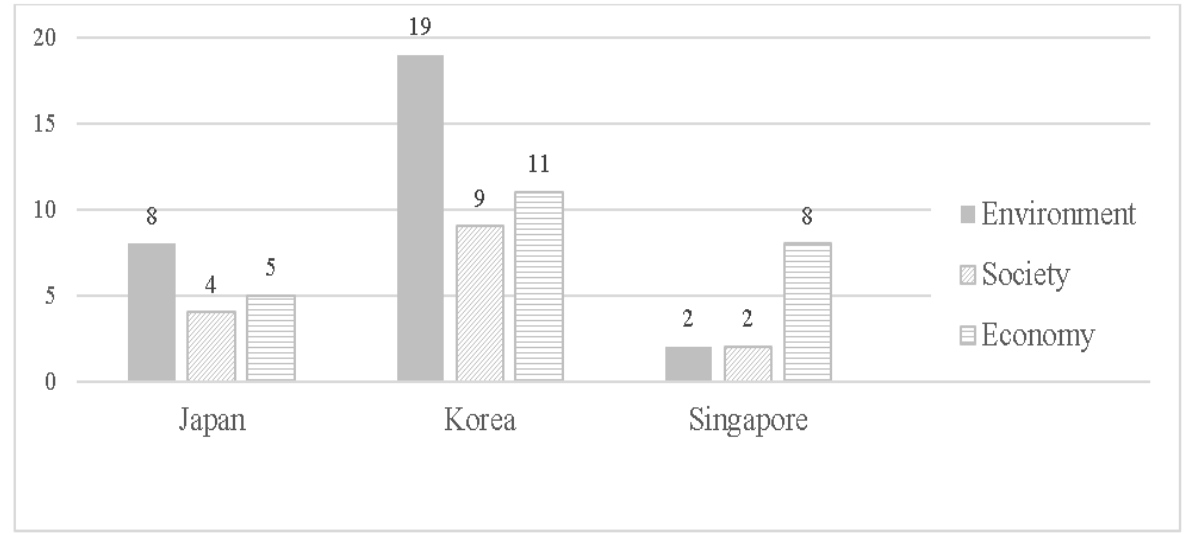

Figure 2. Frequencies of the ESD-related contents by dimension in the three countries

Table 6. Titles of units including ESD-related contents

\begin{tabular}{llll}
\hline Mathematics & & \multicolumn{2}{c}{ Textbooks } \\
\cline { 2 - 4 } $\begin{array}{l}\text { Numbers and } \\
\text { Operations }\end{array}$ & Multiplication of decimal numbers & Korea & Numbers equal or greater than ten- Money \\
& Division of whole numbers & thousands & Whole numbers \\
& Division of decimal numbers & Multiplication of whole numbers & Operations on whole numbers \\
& Estimation & Multiplication of decimal numbers & Four operations on decimal \\
& & Division of whole numbers & numbers \\
& & Division of decimal numbers & Revision problems \\
Geometry & - & Estimation & - \\
Measurement & - & - & - \\
Pattern & Finding patterns & - & Ratio \\
Data and & Graph & Ratios and proportional & Percentages \\
Possibilities & Organization of data & Graph & Average \\
& Average & & Pie chart \\
\end{tabular}

In common, the ESD-related contents were repeatedly presented in the textbooks over several grades, starting from the third or fourth grade. Also, the contents related to environmental, social, and economic dimensions were presented in the textbooks, related mostly to mathematics content domains of Numbers and Operations, Pattern, and Data and Possibilities.

Figure 2 shows the frequencies of the ESD-related contents in the three countries by dimension. It should be noted that the purpose of the study is not for countryby-country comparisons, but for specific details of how the ESD-related contents are presented in the textbooks in each country. Both Japanese and Korean textbooks presented the contents related to the environmental dimension most frequently, whereas the Singaporean ones treated the contents related to the economic dimension most frequently. For all three countries, contents on the social dimension were the least presented. Although the ESD-related contents did not account for much of the overall contents in the textbooks, it is positive that contents about all three dimensions of ESD were involved in the mathematics textbooks.

Table 6 shows the mathematics content domains and titles of units including the ESD-related contents. Regarding the mathematics content domains, most of the contents were related to Numbers and Operations, Pattern, and Data and Possibilities, while none were related to Geometry and Measurement. Regarding the domain of Numbers and Operations, the contents were usually about whole numbers, decimal numbers, and their operations. The content domain of Pattern involved the activities related to finding patterns and ratios. For the content domain of Data and Possibilities, the ESDrelated contents were about representing or interpreting data. This reveals that the ESD-related activities were not addressed evenly in all the mathematics content domains. 
Table 7. Distribution of sub-contents in the environmental dimension by country

\begin{tabular}{|c|c|c|c|c|c|c|c|c|}
\hline Country & $\begin{array}{l}\text { Natural } \\
\text { resources }\end{array}$ & Energy & $\begin{array}{l}\text { Climate } \\
\text { change }\end{array}$ & Biodiversity & $\begin{array}{l}\text { Environmental } \\
\text { problems }\end{array}$ & $\begin{array}{c}\text { Urban \& } \\
\text { rural environments }\end{array}$ & Disaster & $\begin{array}{c}\text { Traffic } \\
\text { pollution }\end{array}$ \\
\hline Japan & & & & & & & & \\
\hline Korea & & & & & & & & \\
\hline Singapore & & & & & & & & \\
\hline
\end{tabular}

Table 8 . Contexts of the environmental dimension by grade level in the three countries

\begin{tabular}{|c|c|c|c|c|}
\hline Country & $3 \mathrm{rd}$ & 4th & 5 th & 6th \\
\hline Japan & - & $\begin{array}{l}\text { Endangered species } \\
\text { Climatic differences } \\
\text { between two regions } \\
\text { Brushing teeth and water } \\
\text { consumption }\end{array}$ & $\begin{array}{l}\text { The amount of non- } \\
\text { burnable garbage } \\
\text { Deforestation } \\
\text { Bottle garbage problem }\end{array}$ & $\begin{array}{l}\text { Rain as a valuable water } \\
\text { resource }\end{array}$ \\
\hline Korea & $\begin{array}{l}\text { Tree planting } \\
\text { Turning off the faucet when } \\
\text { brushing teeth } \\
\text { Collecting wasted milk } \\
\text { carbon and recyclable } \\
\text { bottles } \\
\text { Micro dust and tree } \\
\text { planting } \\
\text { Reducing carbon footprint }\end{array}$ & $\begin{array}{l}\text { Daily water consumption } \\
\text { Domestic water saving } \\
\text { Paper use and wood } \\
\text { consumption } \\
\text { Micro dust days by year } \\
\text { Change of annual peak } \\
\text { temperature } \\
\text { Greenhouse gas emission }\end{array}$ & $\begin{array}{l}\text { Micro dust concentrations } \\
\text { Increase in earthquake } \\
\text { occurrence }\end{array}$ & $\begin{array}{l}\text { Reusing bottles } \\
\text { Ultrafine dust } \\
\text { concentrations and } \\
\text { ingredients } \\
\text { Saving water by using a cup } \\
\text { when brushing } \\
\text { Electric car } \\
\text { Eco-friendly products }\end{array}$ \\
\hline Singapore & & - & Water consumption & Destroyed trees \\
\hline
\end{tabular}

Table 9. Distribution of sub-contents in the social dimension by country

\begin{tabular}{lcccccccc}
\hline Country & $\begin{array}{c}\text { Human } \\
\text { rights }\end{array}$ & $\begin{array}{c}\text { Peace and } \\
\text { security }\end{array}$ & $\begin{array}{c}\text { Cultural } \\
\text { diversity }\end{array}$ & $\begin{array}{c}\text { Social } \\
\text { ethics }\end{array}$ & $\begin{array}{c}\text { Human } \\
\text { health }\end{array}$ & $\begin{array}{c}\text { Gender } \\
\text { equality }\end{array}$ & $\begin{array}{c}\text { Media } \\
\text { literacy }\end{array}$ & $\begin{array}{c}\text { Globalization and } \\
\text { international responsibility }\end{array}$ \\
\hline Japan & & & & & & & \\
Korea & & & & & & \\
Singapore & & & & & & \\
\hline
\end{tabular}

\section{Distribution of the ESD-related Contents in the Textbooks}

The ESD-related contents in the textbooks were classified into the sub-contents and their related topics as shown in Figure 1 and Table 2. As previously stated, since the sub-contents and their related topics of ESD are not focused solely on mathematics, there were the subcontents that were not revealed in the mathematics textbooks. Table 7 shows the distribution of sub-contents in the environmental dimension by country. The shaded cells in Table 7 mean that the corresponding subcontents are presented in the textbooks. Regarding the environmental dimension, all three countries included the contents related to natural resources. Both Japanese and Korean textbooks covered sub-contents of climate change and environmental problems. In each of the textbooks in Japan and Korea, contents about biodiversity and energy were dealt with respectively. These results imply that some sub-contents were combined with mathematics, while others were not. That is, it is assumed that some sub-contents such as natural resources, climate change, and environmental problems are relatively easy to connect to mathematics, compared to others such as urban and rural environments, disasters, and transportation problems.
Table 8 summarizes detailed contexts of the environmental dimension by grade level in the textbooks from the three countries. Some contexts were presented in common across two or three countries, while others were presented only in one country. Specifically, water conservation, forest destruction, and garbage problems were involved as problem contexts across two or three countries. For example, an activity in the Japanese textbook asked how much water would be wasted per day if water would run while brushing teeth. The Korean textbook proposed a problem of finding out how many trees would be planted at tree planting event, which was held as part of protecting the environment. The Singaporean textbook presented a context of calculating the amount of trees previously planted based on the amount of trees destroyed. Although the focus of these activities was to solve the problems using mathematical concepts or principles, it could provide opportunities for students to recognize environment issues and think about sustainable development.

Table 9 shows the distribution of sub-contents in the social dimension by the three countries. All the three countries covered the contents related to peace and security. Also, the Japanese and Korean textbooks included the contents related to human health, while the Japanese and Singaporean textbooks incorporated the contents related to population. Only the Korean 
Table 10. Contexts of the social dimension by grade level in the three countries

\begin{tabular}{|c|c|c|c|c|}
\hline Country & 3rd & 4th & 5 th & 6th \\
\hline Japan & - & Security accidents in school & $\begin{array}{l}\text { Food and healthy life } \\
\text { Security accidents in school }\end{array}$ & $\begin{array}{l}\text { Low birth rate and aging } \\
\text { population }\end{array}$ \\
\hline Korea & $\begin{array}{l}\text { Healthy life } \\
\text { The amount of } \\
\text { sugar in a drink }\end{array}$ & $\begin{array}{l}\text { Decrease in the population and } \\
\text { number of students in a village } \\
\text { Culture diversity by country }\end{array}$ & - & $\begin{array}{l}\text { Investigating rules for safety } \\
\text { school life } \\
\text { Fair distribution }\end{array}$ \\
\hline Singapore & - & - & - & $\begin{array}{l}\text { World population distribution } \\
\text { Security accidents in and } \\
\text { around homes }\end{array}$ \\
\hline
\end{tabular}

Table 11. Distribution of sub-contents in the economic dimension by country

\begin{tabular}{llllll}
\hline Country & $\begin{array}{c}\text { Sustainable food } \\
\text { production }\end{array}$ & $\begin{array}{c}\text { Sustainable } \\
\text { consumption }\end{array}$ & $\begin{array}{c}\text { Sustainability } \\
\text { of companies }\end{array}$ & Market economy & $\begin{array}{c}\text { Narrowing the gap between } \\
\text { the rich and the poor }\end{array}$ \\
\hline Japan & & & & \\
Korea & & & & \\
Singapore & & & \\
\hline
\end{tabular}

Table 12. Contexts of the economic dimension by grade level in the three countries

\begin{tabular}{|c|c|c|c|c|}
\hline Country & 3rd & 4 th & 5 th & 6th \\
\hline Japan & - & $\begin{array}{l}\text { Making-decisions as a } \\
\text { wise consumer }\end{array}$ & $\begin{array}{l}\text { Understanding change in prices } \\
\text { Making-decisions as a wise consumer } \\
\text { Saving money }\end{array}$ & - \\
\hline Korea & $\begin{array}{l}\text { Eating school meals and } \\
\text { saving money } \\
\text { Donation }\end{array}$ & $\begin{array}{l}\text { International } \\
\text { children's sponsorship } \\
\text { Donation }\end{array}$ & - & - \\
\hline Singapore & Market play & - & Making-decisions as a wise consumer & $\begin{array}{l}\text { Donation } \\
\text { Charges for water } \\
\text { consumption }\end{array}$ \\
\hline
\end{tabular}

textbooks included the contents related to cultural diversity and social ethics. Through these results, it could be surmised that some sub-contents of the social dimension are easily incorporated into mathematics; while other sub-contents such as human rights, gender equality, and media literacy are difficult.

Table 10 displays the contexts related to the social dimension by grade level in the three countries. While the Japanese and Korean textbooks presented the contexts related to the social dimension across several grades, the Singaporean textbook showed the contexts only in the sixth grade. Safety-related contexts were dealt with in all three countries. The Japanese textbook asked students to solve problems by analyzing two bar graphs showing the types and percentages of injuries which occurred in two schools. The Korean textbook included a pie chart displaying a result of investigation of the places where safety accidents occurred frequently in schools, followed by a table summarizing the survey results of rules that would be the most essential for safety in school life. The Singaporean textbook showed a pie chart with the causes of accidents in schools and homes. As both home and school are main places for elementary school students, understanding what kinds of safety accidents happen and finding solutions to live a safe life can provide them with a foundation for sustainable development. Furthermore, activities of investigating and analyzing information about safety can be connected with utilizing statistical data in mathematics.
Table 11 shows the distribution of sub-contents in the economic dimension by the three countries. Both Japanese and Singaporean textbooks included the contents related to sustainable consumption, while the Korean textbooks included the contents of sustainable food production and narrowing the gap between the rich and the poor. Compared to the other two dimensions, there were fewer sub-contents for the economic dimension addressed in the textbooks. This implies that connecting economy-related contents with mathematics may not be easy. In this respect, to analyze how the contents of the economic dimension are presented in the textbooks is significant.

Table 12 illustrates detailed contexts of the economic dimension by grade level in the three countries. Sustainable consumption, related to making decisions for finding more reasonable goods and preventing overspending, was included most frequently. These types of activities can give an opportunity for students to consider how to consume limited resources and reuse products for sustainable development. Regarding sustainable food production, the Korean textbook included an activity of calculating money saved when eating all school meals by suggesting the disposal cost of school meals. With reference to the situations of narrowing gaps between the rich and the poor, the Korean textbook suggested contexts in which students could raise money and donate it to neighbors in need. 
Table 13. Frequencies of the ESD-related contents in terms of mathematical features and the expectations from students

\begin{tabular}{lccccc}
\hline & \multicolumn{2}{c}{$\begin{array}{c}\text { Mathematical features } \\
\text { of the contents }\end{array}$} & \multicolumn{3}{c}{ Expectations from students } \\
\cline { 2 - 7 } Country & $\begin{array}{c}\text { To introduce } \\
\text { mathematics concepts, } \\
\text { principles etc. }\end{array}$ & $\begin{array}{c}\text { To apply mathematics } \\
\text { concepts, principles } \\
\text { etc. }\end{array}$ & $\begin{array}{c}\text { Sub-visual material } \\
\text { presenting an ESD-related } \\
\text { situation without a problem }\end{array}$ & $\begin{array}{c}\text { Context for } \\
\text { problem- } \\
\text { solving }\end{array}$ & $\begin{array}{c}\text { Context for problem- } \\
\text { solving and considering } \\
\text { sustainability }\end{array}$ \\
\hline Japan & 6 & 11 & 3 & 10 & 4 \\
Korea & 22 & 17 & 1 & 31 & 7 \\
Singapore & 0 & 12 & 0 & 12 & 0 \\
\hline
\end{tabular}

Table 14. Summary of activities in the Japanese textbooks expected for students both to solve problems and to consider ESD

\begin{tabular}{|c|c|c|c|}
\hline $\begin{array}{l}\text { Grade } \\
\text { Unit title }\end{array}$ & $\begin{array}{l}\text { Activity } \\
\text { topic }\end{array}$ & Contents of activity & Relation to ESD \\
\hline $\begin{array}{l}5-2 \\
\text { Percentages }\end{array}$ & $\begin{array}{l}\text { A story in } \\
\text { arithmetic: } \\
\text { Lost forest }\end{array}$ & $\begin{array}{l}\text { Calculate the percentages of forest decline by looking at } \\
\text { the areas of forest in } 2000 \text { and } 2005 \text { in various regions } \\
\text { Forecast area of the forest in } 2020 \text { based on the data }\end{array}$ & $\begin{array}{l}\text { Recognize the benefits of forests. Anticipate } \\
\text { the future of the forest. Have a mindset to } \\
\text { protect forest }\end{array}$ \\
\hline $\begin{array}{l}5-2 \\
\text { (after all } \\
\text { units) }\end{array}$ & $\begin{array}{l}\text { Waste } \\
\text { reduction } \\
\text { and carbon } \\
\text { dioxide }\end{array}$ & $\begin{array}{l}\text { Analyze the data about garbage presented in a bar } \\
\text { graph, an angled line, and a circle graph } \\
\text { Calculate the number of cedar trees based on the } \\
\text { amount of carbon dioxide }\end{array}$ & $\begin{array}{l}\text { Understand seriousness of the garbage } \\
\text { problem. Confirm that incineration of waste } \\
\text { leads to the generation of carbon dioxide, } \\
\text { which is the main cause of global warming }\end{array}$ \\
\hline $\begin{array}{l}6-1 \\
\text { (after all } \\
\text { units) }\end{array}$ & $\begin{array}{l}\text { Rain is a } \\
\text { valuable } \\
\text { resource }\end{array}$ & $\begin{array}{l}\text { Interpret data about daily water use at home presented } \\
\text { in a bar graph, a circle graph, and a table } \\
\text { Calculate the amount of rainwater stored }\end{array}$ & $\begin{array}{l}\text { After calculating how much water is used at } \\
\text { home and how much rain is stored, make a } \\
\text { commitment to use water carefully }\end{array}$ \\
\hline $\begin{array}{l}6-2 \\
\text { Various } \\
\text { graphs }\end{array}$ & $\begin{array}{l}\text { Various } \\
\text { graphs }\end{array}$ & $\begin{array}{l}\text { Interpret the graphs about population of Japan in } 1970 \\
\text { and } 2005 \\
\text { Share what you noticed and predict the future of } \\
\text { society }\end{array}$ & $\begin{array}{l}\text { Understand the social changes: increase of } \\
\text { low birth rate and the increase of aging. } \\
\text { Have a mindset for a sustainable society }\end{array}$ \\
\hline
\end{tabular}

The contexts show potential to address the sustainability of the economic dimension in mathematics.

\section{Connections of the ESD-related Contents with Mathematics}

We analyzed connections of the ESD-related contents with mathematics in two aspects, both the mathematics features of the contents and the expectations from students. Regarding the mathematics features of the contents, we explored whether the ESD-related contents were employed to introduce mathematics or to apply it to mathematics. For the expectations from students, we examined whether the ESD-related contents were merely used as a sub-visual material presenting an ESDrelated situation without a problem, or used as a context for problem-solving, or used to consider sustainability as well as problem-solving. Table 13 illustrates the results of analysis in the three countries.

Regarding the mathematical features of the ESDrelated contents, the Korean textbooks showed a markedly different result than the Japanese and the Singaporean textbooks. That is, in the Korean textbooks, the ESD-related contents were presented more often as introduction activities than as application activities. In contrast, both Japanese and Singaporean textbooks included more activities of applying mathematical concepts to the problem situations. Contrary to the Korean and Japanese textbooks that contained both introduction and application activities, the Singaporean textbooks covered only application activities. For instance, in the Korean textbook, the concept of a fivedigit number was introduced in the unit, numbers equal or greater than ten-thousands, with the problem situation of donating $\$ 20,000$ and $\$ 30,000$ per month respectively by two families to support international children support organizations. In the Singaporean textbook, the problem in the unit of average was to find out how many cans one person picked up when the other person and another person picked up 18 cans and 12 cans respectively and the average number of cans picked up was 15. The ESD-related situation can be solved by utilizing the previously learned concept of mean. These examples reveal that ESD-related contents can be presented in various ways, such as when introducing or applying mathematical concepts.

Regarding the expectations from students, the percentage of contexts used for problem-solving was the highest for all three countries. It means that the main purpose of the activities with the ESD-related contents was to solve problems using mathematical concepts or principles. Examples of such activities were as follows: finding the amount of protein in food for a healthy diet in the Japanese textbook; computing the number of trees used in tree planting events as part of environmental protection in the Korean textbook; and identifying the price of water consumption to conserve water resources in the Singaporean textbook. 
Table 15. Summary of activities in the Korean textbooks expected for students both to solve problems and to consider ESD

\begin{tabular}{|c|c|c|c|}
\hline $\begin{array}{l}\text { Grade } \\
\text { Unit title }\end{array}$ & Activity topic & Contents of activity & Relation to ESD \\
\hline $3-1$ & Exploratory mathematics: & Calculate how much calories we have & Create exercise plans for a healthy \\
\hline Addition and & What should we do to live & in eating snacks & lifestyle considering date, time, calories \\
\hline subtraction & a healthy life? & Create exercise plans & consumption, and types of exercise \\
\hline $3-2$ & Exploratory mathematics: & Investigate how much sugar is in & Recognize the amount of sugar in \\
\hline $\begin{array}{l}\text { Arrangement } \\
\text { of data }\end{array}$ & $\begin{array}{l}\text { Which drink should we } \\
\text { choose? }\end{array}$ & $\begin{array}{l}\text { different beverages } \\
\text { Represent the data in pictogram } \\
\text { Share what you felt through the } \\
\text { activity }\end{array}$ & $\begin{array}{l}\text { beverages. Pledge to live a healthy life } \\
\text { by drinking beverages with less sugar }\end{array}$ \\
\hline $4-1$ & Exploratory mathematics: & Calculate how many trees we need to & Understand that many trees are needed \\
\hline $\begin{array}{l}\text { Multiplication and } \\
\text { division }\end{array}$ & $\begin{array}{l}\text { How much paper are we } \\
\text { using? }\end{array}$ & $\begin{array}{l}\text { make a textbook } \\
\text { Share what you felt through the } \\
\text { activity }\end{array}$ & $\begin{array}{l}\text { to make paper. Share one's feelings by } \\
\text { making advertisements or cartoons }\end{array}$ \\
\hline $\begin{array}{l}4-2 \\
\text { Angled } \\
\text { line graph }\end{array}$ & $\begin{array}{l}\text { Exploratory mathematics: } \\
\text { Let's look into } \\
\text { our area }\end{array}$ & $\begin{array}{l}\text { Investigate the number of elementary } \\
\text { school students and the number of } \\
\text { population in the area } \\
\text { Choose a topic related our area and } \\
\text { explore it } \\
\text { Share what you felt through the } \\
\text { activity }\end{array}$ & $\begin{array}{l}\text { Choose an interesting topic related to } \\
\text { our area (e.g., population, precipitation, } \\
\text { student, environment, etc.). Organize } \\
\text { research data and represent them in a } \\
\text { graph. Endeavor to make our area } \\
\text { sustainable }\end{array}$ \\
\hline $\begin{array}{l}4-2 \\
\text { (after all units) }\end{array}$ & $\begin{array}{l}\text { Seeing the world through } \\
\text { mathematics }\end{array}$ & $\begin{array}{l}\text { Explore the data presented } \\
\text { greenhouse gas emissions in Korea } \\
\text { Create posters to signal the dangers } \\
\text { of global warming and talk about } \\
\text { ways to reduce greenhouse gases }\end{array}$ & $\begin{array}{l}\text { Recognize the trends in greenhouse gas } \\
\text { emissions and the dangers of global } \\
\text { warming and make a commitment to } \\
\text { reduce them }\end{array}$ \\
\hline $6-1$ & Challenging mathematics: & Check the reuse status of bottles & of reuse of empty bottles. \\
\hline Ratio and rate & $\begin{array}{l}\text { Let's read the environment } \\
\text { through mathematics }\end{array}$ & $\begin{array}{l}\text { Calculate the increase in empty bottle } \\
\text { deposits and pose a problem }\end{array}$ & $\begin{array}{l}\text { Commit to reuse bottles to protect the } \\
\text { environment }\end{array}$ \\
\hline $6-2$ & Challenging mathematics: & Calculate the profits of two regions & Consider fair distribution and connect \\
\hline $\begin{array}{l}\text { Proportional } \\
\text { expression and } \\
\text { proportional } \\
\text { distribution }\end{array}$ & Let's split it up fairly & $\begin{array}{l}\text { according to the different distribution } \\
\text { methods respectively. } \\
\text { Think about which is the fairest } \\
\text { method } \\
\text { Pose a problem that meets the } \\
\text { conditions }\end{array}$ & to sustainable society \\
\hline
\end{tabular}

Meanwhile, both Japanese and Korean textbooks included the activities to make students to consider sustainability as well as to solve problems. These types of activities first allowed students to solve mathematics problems and furthermore to think about sustainability inherent in the activities. This is meaningful in that it can give opportunities for students to understand sustainability and recognize the role of public participation in community from a perspective of sustainable development. Such activities were related to mainly environmental and social dimensions. The Japanese textbooks involved the activities four times. Table 14 summarizes the units, topics, contents of the activities, and relation to ESD in the Japanese textbooks. The themes of those activities were the reduction of forests, the waste problems, the precious resources of rain, and the low birthrate and aging society. These activities were commonly organized to solve the mathematics problems embedded in sustainabilityrelated topics by activating the core mathematical concepts learned. The activities in the Japanese textbooks allowed students to fully understand the issues of sustainable development by explaining the focused situations in detail or presenting various types of data. After analyzing the presented data in several ways, students had opportunities to share their thoughts on how to act for their sustainable future.

As for the Korean textbooks, the activities including both solving problems and considering sustainability were presented seven times. Table 15 summarizes the units, topics, contents of the activities, and relation to ESD in the Korean textbooks. The contexts related to healthy life, the amount of sugar in beverages, the trend of declining population and number of elementary school students in the region, greenhouse gas emissions, etc. Like the counterparts in the Japanese textbooks, the activities were related to mainly the environmental and social dimensions. The activities in the Korean textbooks asked students to engage in student-led activities such as making exercise plans, making posters, or investigating their own regions.

Looking closely at one of the activities presented in Table 14, an activity titled Lost Forest in the Japanese textbook was supposed to impart an understanding of the benefits of forests and to calculate areas of 
deforestation by region. It explained that the area of forests was decreasing due to logging and forest fires despite lots of benefits of the forest and it could lead to global warming. The activity displayed forest areas in various regions in 2000 and 2005 in a table and asked students to calculate the percentages of the deforested areas and to put the calculation results in the blanks of the table. Furthermore, it posed a question to consider what would happen in the future if the forest was reducing in such a way.

As for the Korean activities presented in Table 15, the activity titled Seeing the World through Mathematics aimed at understanding the seriousness of greenhouse gas emissions in Korea by analyzing the data and making a poster to alert people to the dangers of global warming. It first presented the annual greenhouse gas emissions per capita in a table and a graph. Included was an explanation that greenhouse gases make the temperature of the earth as hot as a greenhouse and global warming is a phenomenon in which the earth gets hotter and hotter due to these greenhouse gases. The activity then directed students to compute greenhouse gas emissions per capita and the increase in greenhouse gas emissions from 1995 to 2015. Finally, students were to imagine what would happen if this continues and to create a poster to warn the risk of global warming. Both examples in Japanese and Korean textbooks presented ESD-related issues and gave an opportunity for students to anticipate what would happen if such issues continue. Predicting future is significant in order for students to recognize the seriousness of the sustainability-related issues and to make active participation possible.

Based on the results of the textbook analysis, the connection between sustainability and mathematics can be divided into two ways: passive way and active way. A passive way of connection is to present the issues of sustainable development mainly as the contexts or backgrounds for solving problems, and the opportunity to think further or discuss sustainability is not included explicitly in the activities. In contrast, an active way of connection is to provide detailed explanations about sustainability issues and to present students with sustainability-related activities. In this study, the Japanese and Korean textbooks showed differences in terms of active way of connection: The Korean textbooks focused more on recognition and active participation by students, while the Japanese textbooks focused more on analyzing related data and predicting future trends.

\section{DISCUSSION}

Given the importance of ESD in elementary school, this study showed that there were promising results on sustainable development in the mathematics textbooks of Japan, Korea, and Singapore. Some ESD-related activities presented in the textbooks provided opportunities for students not only to solve related problems mathematically but also to connect them to sustainability. Based on the results, this study provides implications for guidance on ESD in elementary school mathematics.

More active and systematic ways to provide ESD need to be prepared in mathematics curricula and textbooks. This study revealed that the selected elementary mathematics textbooks in the three countries included the ESD-related contents of three dimensions of ESD: environment, society, and economy. Most of the contents were related to the mathematics content domains of Numbers and Operations, Pattern, and Data and Possibilities. On the one hand, these results are positive in that there is a possibility of implementing ESD in elementary school mathematics. On the other hand, there is much room to reflect ESD in mathematics curricula and textbooks more actively and systematically, given that most of the contents were related merely to the environmental dimension and served as the contexts for solving problems.

In order to effectively implement ESD in school mathematics, it is fundamental to reconstruct or reorient the mathematics curriculum. For example, the Australian Curriculum reoriented and emphasized sustainability as a priority of curriculum that connects related contents across learning strands and subjects (Australian Curriculum, 2015; Australian Curriculum Assessment and Reporting Authority, 2015). By prioritizing sustainability in the curriculum, students can have an opportunity to develop the knowledge, skills, values, and world views required to envision a more sustainable life. Mathematics also can be taught in relation to sustainability through a cross-curriculum priority, even though it is not a subject that deals directly with sustainability. According to the Australian curriculum, mathematical understanding and skills are essential in measuring, monitoring, and quantifying changes in ecological, social, and economic systems. Statistical analysis of data also enables to predict probable futures and to advise decision-making for preferred futures. In this regard, efforts should be made to reflect ESD in the mathematics curriculum to highlight the importance of sustainability and guide the direction.

A cautionary remark is that there is no guarantee that ESD-related contents will be implemented in lessons although they are stated in the curriculum document. According to UNESCO (2012), there are inconsistencies in the curriculum in which sustainability topics are presented but are not being taught. The reasons for this included: no obligation to incorporate sustainability into classroom activities; no recognition of the sustainabilityrelated contents by teachers; and lack of teaching skills to implement ESD (UNESCO, 2012). In this respect, we need to find various ways to make ESD more viable and implementable in lessons, such as the development of mathematics textbooks connected directly to 
sustainability or the supply of teacher manuals including the significance of ESD and illustrative teaching strategies that can be embedded in mathematics lessons.

Another related aspect involves the necessity for a specific framework to incorporate ESD more systematically in mathematics textbooks. The results of this study showed that the ESD-related contents were included in the selected textbooks, even though the textbooks did not stand for ESD explicitly. The results of this study also showed that both a passive and an active way were employed in connecting mathematics to ESD in the textbooks. While the former provided opportunities for students to encounter sustainable development while learning mathematical concepts and principles, the latter provided opportunities for them to understand and take account of ESD in depth beyond solving the given problems. Which method is more practical or effective may be different depending on how each country would like to incorporate ESD to mathematics textbooks. Nevertheless, what is clear is that the pros and cons of each method need to be understood and utilized in the process of developing textbooks.

Two aspects may be considered in developing mathematics-specific ESD frameworks. One is which mathematical contents will be extracted and organized in relation to ESD, and the other is how the contents will be presented in the textbooks. Regarding the ESDrelated contents, the current study found that the contents in the three selected textbook series were involved in the mathematics domains of Numbers and Operations, Patterns, and Data and Possibilities. In other words, the ESD-related contents in Geometry or Measurement were not included in the textbooks. However, other studies introduced sustainable mathematics contents across more various domains. For instance, the Board of Studies New South Wales (2012) suggested the characteristics of mathematical contents for sustainability as follows:

\section{"to measure and evaluate sustainability changes over time and develop a deeper appreciation of the world through such aspects of mathematics as patterning, three-dimensional space, symmetry and tessellations" (p. 42).}

Serow (2015) also explained mathematical activities for ESD in detail across measurement, space and geometry, number, statistics, and patterns and algebra. This means that ESD can be linked in different domains of mathematics, leading us to select and organize more various mathematics content domains.

Regarding the presentation of the ESD-related contents in the textbooks, the current study demonstrated different aspects in terms of the cognitive efforts required by students. Some ESD-related contents were used to provide materials or contexts about sustainability, while others were to require students to solve problems both mathematically and sustainably. The three selected textbook series of this study presented most ESD-related contents as sub-materials or contexts for problems. In-depth consideration of sustainability in mathematics lessons, which are already tight to deal mainly with mathematics contents, requires considerable time and effort. However, this seems essential, weighing the importance of attitude change and motivation of students in ESD development (Rode \& Michelsen, 2008).

Of note is that this study did not aim to judge which textbook is the best one for teaching and learning sustainable development in elementary schools. As textbooks are usually regarded as an inseparable part of teaching and learning, the potential impact of textbooks on mathematics instruction cannot be ruled out. By focusing on the contents related to sustainable development in the textbook series, the study is expected to provide information how sustainable development is addressed in the Japanese, Korean, and Singaporean textbooks.

Author contributions: All authors have sufficiently contributed to the study, and agreed with the results and conclusions.

Funding: No funding source is reported for this study.

Declaration of interest: No conflict of interest is declared by authors.

\section{REFERENCES}

Australian Curriculum. (2015). Sustainability. https:/ / www.australiancurriculum.edu.au/f-10curriculum/cross-curriculum-priorities / sustainability /

Australian Curriculum Assessment and Reporting Authority. (2015). Sustainability. https://www. acara.edu.au/curriculum/foundation-year-10/ cross-curriculum-priorities / sustainability-ccp

Bartusevica, A., \& Cedere, D. (2003). Eco-team formation in Latvia and their role in environmental education. Journal of Baltic Science Education, 2(4), 5-11.

Barwell, R. (2018). Some thoughts on a mathematics education for environmental sustainability. In P. Ernest (Ed.), The philosophy of mathematics education today (pp. 145-160). Springer. https://doi.org/10. 1007/978-3-319-77760-3_9

Bayda, N. I., \& Sutliff, G. (2020). Comparing extracted and stipulated definitions in Algebra 1 textbooks and Khan Academy. International Electronic Journal of Mathematics Education, 15(2), em0579. https:// doi.org/10.29333/iejme/7601

Board of Studies New South Wales (2012). NSW syllabus for the Australian curriculum: Mathematics K-10 syllabus. https://educationstandards.nsw.edu.au/ wps/portal/nesa/k-10/learning-areas/ mathematics/mathematics-k-10/version-log 
Charalambous, C. Y., Delaney, S., Hsu, H., \& Mesa, V. (2010). A comparative analysis of the addition and subtraction of fractions in textbooks from three countries. Mathematical Thinking and Learning, 12(2), 117-151.

https:/ / doi.org/10.1080/10986060903460070

Choy, B. H., Lee, M. Y., \& Mizzi, A. (2020). Insights into the teaching of gradient from an exploratory study of mathematics textbooks from Germany, Singapore, and South Korea. International Electronic Journal of Mathematics Education, 15(3), em0592. https://doi.org/10.29333/iejme/8273

Collars, C., Koay, P. L., Lee, N. H., Ong, B. L., \& Tan, C. S. (2014a). Shaping maths coursebook 3A. Marshall Cavendish.

Collars, C., Koay, P. L., Lee, N. H., Ong, B. L., \& Tan, C. S. (2014b). Shaping maths coursebook 5A. Marshall Cavendish.

Collars, C., Koay, P. L., Lee, N. H., Ong, B. L., \& Tan, C. S. (2014c). Shaping maths coursebook 5B. Marshall Cavendish.

Collars, C., Koay, P. L., Lee, N. H., Ong, B. L., \& Tan, C. S. (2014d). Shaping maths coursebook 6A. Marshall Cavendish.

Collars, C., Koay, P. L., Lee, N. H., Ong, B. L., \& Tan, C. S. (2014e). Shaping maths coursebook 6B. Marshall Cavendish

Elliott, S., \& Davis, J. (2009). Exploring the resistance: An Australian perspective on educating for sustainability in early childhood. International Journal of Early Childhood, 41(2), 65-77. https:/ / doi.org/10.1007/bf03168879

Fan, L., \& Zhu, Y. (2007). Representation of problemsolving procedures: A comparative look at China, Singapore, and US mathematics textbooks. Educational studies in Mathematics, 66(1), 61-75. https: / / doi.org/10.1007/s10649-006-9069-6

Fan, L., Zhu, Y., \& Miao, Z. (2013). Textbook research in mathematics education: development status and directions. ZDM, 45(5), 633-646. https://doi.org/ $10.1007 / \mathrm{s} 11858-013-0539-x$

Hedefalk, M., Almqvist, J., \& Östman, L. (2015). Education for sustainable development in early childhood education: A review of the research literature. Environmental Education Research, 21(7), 975-990. https://doi.org/10.1080/13504622.2014. 971716

Hesse-Biber, S. N. (2010). Mixed methods research: Merging theory with practice. The Guilford Press. https:/ / doi.org/10.1177/1473325011433761b

Joutsenlahti, J., \& Perkkilä, P. (2019). Sustainability development in mathematics education: A case study of what kind of meanings do prospective class teachers find for the mathematical symbol
“2/3"?. Sustainability, 11(2), 457. https://doi.org/ $10.3390 /$ su11020457

Kang, W. (2010). A content analysis of education for sustainable development in 2007 revised middle school environment textbooks. Korea Association of Geographic and Environmental Education, 18(3), 339354.

https:/ / doi.org/10.17279/jkagee.2010.18.3.339

Kennelly, J., Taylor, N., \& Serow, P. (2011). Education for sustainability and the Australian curriculum. Australian Journal of Environmental Education, 27(2), 209-218. https:/ / doi.org/10.1375/ajee.27.2.209

Levin, S. (2015). What mathematics can do for sustainability. Bulletin of Mathematical Biology, 77(2), 251-253. https://doi.org/10.1007/s11538-014-0038 $-4$

Li, Y. (2000). A comparison of problems that follow selected content presentations in American and Chinese mathematics textbooks. Journal for Research in Mathematics Education, 31, 234-241. https:/ / doi.org/10.2307/749754

Li, Y., Chen, X., \& An, S. (2009). Conceptualizing and organizing content for teaching and learning in selected Chinese, Japanese and US mathematics textbooks: The case of fraction division. ZDM, 41(6), 809-826. https://doi.org/10.1007/s11858009-0177-5

Liu, Z., Yang, H. C., \& Shiau, Y. C. (2020). Investigation on evaluation framework of elementary school teaching materials for sustainable development. Sustainability, 12(9), 3736. https://doi.org/10. 3390/su12093736

Martínez-Medina, R., \& Arrebola, J. C. (2019). Analysis of sustainability activities in Spanish elementary education textbooks. Sustainability, 11(19), 5182. https:/ / doi.org/10.3390/su11195182

McKeown, R., Hopkins, C. A., Rizi, R., \& Chrystalbridge, M. (2002). Education for sustainable development toolkit. Energy, Environment and Resources Center, University of Tennessee. https:/ / www.ramsar.org/ sites/default/files/documents/library/esd_toolki t_version_2.pdf

Miedijensky, S., \& Abramovich, A. (2019). Implementation of "education for sustainability" in three elementary schools-what can we learn about a change process? EURASIA Journal of Mathematics, Science and Technology Education, 15(10), 1754. https:// doi.org/10.29333/ejmste/109145

Ministry of Education (2020a). 3-2 Mathematics textbook. Visang.

Ministry of Education (2020b). 4-1 Mathematics textbook. Visang.

Ministry of Education (2020c). 4-2 Mathematics textbook. Visang. 
Ministry of Education (2020d). 5-2 Mathematics textbook. Visang.

Ministry of Education (2020e). 6-1 Mathematics textbook. Visang.

Ministry of Education (2020f). 6-2 Mathematics textbook. Visang.

Mullis, I. V. S., Martin, M. O., Foy, P., Kelly, D. L., \& Fishbein, B. (2020). TIMSS 2019 International results in mathematics and science. Boston College, TIMSS \& PIRLS International Study Center. https:/ / timssandpirls.bc.edu/timss2019/internati onal-results/

Prince, C. (2010). Sowing the seeds: Education for sustainability within the early years curriculum. European Early Childhood Education Research Journal, 18(3), 423-434. https://doi.org/10.1080/1350293x. 2010.500082

Renert, M. (2011). Mathematics for life: Sustainable mathematics education. For the Learning of Mathematics, 31(1), 20-26.

Rezat, S., Fan, L., \& Pepin, B. (2021). Mathematics textbooks and curriculum resources as instruments for change. ZDM, 53(6), 1189-1206. https://doi.org/10.1007/s11858-021-01309-3

Rode, H., \& Michelsen, G. (2008). Levels of indicator development for education for sustainable development. Environmental Education Research, 14(1), 19-33. https:/ / doi.org/10.1080/13504620701 843327

Roe, J., deForest, R., \& Jamshidi, S. (2018). Mathematics for sustainability. Springer. https://doi.org/10.1007/ 978-3-319-76660-7

Serow, P. (2015). Education for sustainability in primary mathematics education. In N. Taylor., F. Quinn., \& C. Eames. (Eds.), Educating for sustainability in primary schools: Teaching for the future (pp. 177-194). Sense Publisher. https://doi.org/10.1007/978-946300-046-8_9

Stein, M. K., Remillard, J., \& Smith, M. S. (2007). How curriculum influences student learning. Second Handbook of Research on Mathematics Teaching and Learning, 1(1), 319-370.

Summers, M., \& Kruger, C. (2003). Teaching sustainable development in primary schools: Theory into practice. Curriculum Journal, 14(2), 157-180. https:/ / doi.org/10.1080/09585170302836

The World Commission on Environment and Development. (1987). Our common future. Oxford University Press. https:/ / doi.org/10.2307/2621529

Tokyo Shoseki. (2011a). Atarashi sansuu 3-1. Tokyo Shoseki Publishing.

Tokyo Shoseki. (2011b). Atarashi sansuu 4-1. Tokyo Shoseki Publishing.

Tokyo Shoseki. (2011c). Atarashi sansuu 4-2. Tokyo Shoseki Publishing.

Tokyo Shoseki. (2011d). Atarashi sansuu 5-1. Tokyo Shoseki Publishing.

Tokyo Shoseki. (2011e). Atarashi sansuu 5-2. Tokyo Shoseki Publishing.

Tokyo Shoseki. (2011f). Atarashi sansuu 6-1. Tokyo Shoseki Publishing.

Tokyo Shoseki. (2011g). Atarashi sansuu 6-2. Tokyo Shoseki Publishing.

Törnroos, J. (2005). Mathematics textbooks, opportunity to learn and student achievement. Studies in Educational Evaluation, 31(4), 315-327. https:/ / doi.org/10.1016/j.stueduc.2005.11.005

UN. (2015). United nations sustainable development summit 2015. https://sustainabledevelopment.un.org/ post2015/summit

UNESCO. (2012). Education for sustainable development sourcebook. https://unesdoc.unesco.org/ark:/ 48223/pf0000216383.locale $=\mathrm{en}$

Woo, Y. L., Mokhtar, M., Komoo, I., \& Azman, N. (2012). Education for sustainable development: a review of characteristics of sustainability curriculum. OIDA International Journal of Sustainable Development, 3(8), 33-44.

Yuniarti, Y. S., Hasan, R., \& Ali, M. (2019). Competencies of education for sustainable development related to mathematics education in senior high school. Journal of Physics: Conference Series, 1179(2019), 1-7. https:/ / doi.org/10.1088/1742-6596/1179/1/ 012075

Zehetmeier, S., \& Krainer, K. (2011). Ways of promoting the sustainability of mathematics teachers' professional development. ZDM, 43(6-7), 875-887. https:/ / doi.org/10.1007/s11858-011-0358-x

\section{https://www.ejmste.com}

